\title{
Replacing soybean oil with increasing levels of soybean acid oil in diets of coturnix quails (Coturnix coturnix coturnix) and the effects on egg quality
}

\author{
ALINE A.P. ROLL ${ }^{1}$, JULIANA FORGIARINI ${ }^{1}$, EDUARDO G. XAVIER ${ }^{2}$, DÉBORA \\ C.N. LOPES ${ }^{2}$, VICTOR F.B. ROLL ${ }^{2}$ and FERNANDO RUTZ ${ }^{2}$ \\ ${ }^{1}$ Programa de Pós-Graduação em Zootecnia, Universidade Federal de Pelotas, Faculdade \\ de Agronomia Eliseu Maciel, Departamento de Zootecnia, Av. Eliseu Maciel, Campus \\ Universitário, s/n, Caixa Postal 354, 96010-900 Capão do Leão, RS, Brazil \\ ${ }^{2}$ Universidade Federal de Pelotas, Faculdade de Agronomia Eliseu Maciel, Departamento de Zootecnia, Av. \\ Eliseu Maciel, Campus Universitário, s/n, Caixa Postal 354, 96010-900 Capão do Leão, RS, Brazil
}

Manuscript received on April 21, 2017; accepted for publication on June 19, 2017

\begin{abstract}
The effects of increasing levels of soybean acid oil in diets of quails on the quality of eggs were evaluated over a period of 56 days. A completely randomized design with five treatment levels of soybean acid oil ( 0 , $2,4,6$, and $8 \%$ ) as a replacer for soybean oil and eight replicates of two quails each were used. A total of 240 fresh eggs were used for quality analysis, and 400 eggs were stored at $23^{\circ} \mathrm{C}$ over a period of $0,7,14$, 21 , and 28 days for analysis of shelf-life. Polynomial regression and ANOVA with repeated measurements and Tukey's tests were used. Soybean acid oil linearly increased the intensity of red ( $\mathrm{a}^{*}=-5.26+0.14 \mathrm{x}$, $\left.\mathrm{R}^{2}=0.89, \mathrm{P}=0.01\right)$ and yellow $\left(\mathrm{b}^{*}=42.32+0.44 \mathrm{x}, \mathrm{R}^{2}=0.88 \mathrm{P}=0.01\right)$. All other variables of egg quality were not affected by the treatments, with the exception of sensory attributes, such as odor and aftertaste, which were more pronounced with soybean acid oil. In conclusion, soybean acid oil affects the intensity of yellow and red color of the yolk. Trained assessors detected differences in odor and aftertaste of eggs when soybean acid oil was included in the quail diet.
\end{abstract}

Key words: Alternative ingredient, free fatty acids, poultry, sensory analysis, shelf life.

\section{INTRODUCTION}

The use of oils and fats in diets of birds is a useful tool to enhance the caloric increment of diets, improve palatability, and facilitate the digestion and absorption of non-lipid ingredients (Santos et al. 2009).

Degummed soybean oil is the most commonly oil used in Brazil's poultry nutrition industry. It

Correspondence to: Aline Piccini Roll

E-mail: apiroll@yahoo.es is yellow to lightly red and primarily consists of triglycerides, accompanied by smaller proportions of free fatty acids and sterols. Soybean presents considerable amounts of vitamin E, with $10.99 \mathrm{mg}$ of $\alpha$-tocopherol, $62.4 \mathrm{mg}$ of $\gamma$-tocopherol, and 20.38 of $\delta$-tocopherol per 100 grams of oil. Vitamin E is a powerful lipid soluble antioxidant and scavenges lipid peroxyl radicals by donating hydrogen from the phenolic group on the chromanol ring (Jiang 2014), thereby protecting cells from harmful oxygen-free radicals. However, to date, there is no 
study indicating the vitamin E content of soybean acid oil (SAO). Certain types of oil by-products, such as acid oils, are of interest for the livestock industry due to their potential use as alternative energetic sources for feed manufacturing. Soybean acid oil is dark brown colored and a product of soybean oil refinement, a process which removes free fatty acids, phosphatides and gums, and other substances (Mounts 1981), which may account for 75 to $95 \%$ of the fatty acids present in the native oils (Freitas et al. 2005). It is also rich in yellow pigments (910 $\mathrm{mg} \mathrm{kg}^{-1}$ of xanthophyll) and can therefore improve skin pigmentation of broilers on a sorghum-based diet, equivalent to $48 \%$ of the value obtained with synthetic pigments when included at a level of $3.9 \%$ in the feed formulation (Pardio et al. 2001).

However, these acid oils present high amounts of fatty acids, such as free fatty acids, and because they do not have enough monoglycerides (MG) to promote good absorption, they have a low digestibility (Raber et al. 2009).

According to Ormenese et al. (2004), modification of hen diets can affect the quality and sensory properties of eggs. Pardio et al. (2005) worked with soybean soapstock in the diet of laying hens and reported no difference in the quality of eggs compared to a control diet with soybean oil at 100\%. Similarly, Senköylü et al. (2004) evaluated the use of sunflower acid oil, stearin (a residue of sunflower seed oil extraction), and Bergafat (a commercial blend of acid oil) in the diet of laying hens and found no significant effects on laying performance and egg weight.

However, results related to the use of soybean acid oil (SAO) in diets of quails are practically non-existent, mainly related to quality and sensory characteristics, such as odor, flavor, and color, of eggs of quails fed diets containing acid oils and high levels of FFA. According to Moura et al. (2009), the addition of non-conventional ingredients to the diets of birds should not negatively affect the quality and sensory characteristics of the eggs.

In this context, the objective of this trial was to evaluate sensory characteristics and the internal and external quality of fresh and stored eggs of quails fed diets with increased levels of soybean acid oil in place of soybean oil.

\section{MATERIALS AND METHODS}

The trial was conducted at the Laboratory of Teaching and Zootechnical Experimentation, Professor Renato Peixoto, of the Department of Animal Sciences/UFPEL, from June to September 2015. The research was conducted according to the Federal University of Pelotas (UFPEL) Ethics Committee on Animal Experimentation (protocol number 1433-2015).

A total of eighty 180-day-old dual-purpose quails (Coturnix coturnix coturnix) were randomly allotted to five treatments with eight replications each and distributed into 40 metallic cages (two birds per pen - experimental unit) equipped with manual feeders and automatic nipples.

Two periods of 28 days were evaluated and the quails were individually weighed at the first day and at the end of each period. The room had a controlled temperature $\left(23^{\circ} \mathrm{C} \pm 1\right)$ and lightening $(17 \mathrm{~h} /$ day $)$. Daily temperature and humidity were registered every day with a digital thermo hygrometer.

In the pre-experimental period, all birds were fed the same basal corn-soybean meal diet formulated to contain $23.9 \%$ crude protein and $2.900 \mathrm{kcal} / \mathrm{kg}$ metabolizable energy. The experimental diets, in meal form, were based on corn and soybean meal and formulated according to the requirements of the quails (Silva et al. 2012). The treatments originated from the formulation of a basal diet $(2,900 \mathrm{kcal} \mathrm{ME} / \mathrm{kg}$ and $22 \% \mathrm{CP})$, in which levels up to $8 \%$ of SAO in replacement of SO were added. 
Table I shows the composition of the diets with the different concentrations of SAO and Soybean oil (SO) to produce growing levels of FFA. Both SAO and SO were previously mixed with soybean meal. The SAO was preheated to facilitate the mixing. Each bird received $45 \mathrm{~g}$ of feed/day, and the leftovers were registered at the end of each 28 days. The analysis of SAO was run at CBO Análises Laboratoriais, Campinas, São Paulo (Table II). Table III shows several fatty acid profiles of SO reported in the literature.

\section{ANALYSIS OF THE QUALITY OF FRESH AND STORED EGGS}

For the quality analysis, 240 fresh eggs produced in the last three days of the experimental period (after eight weeks of feeding experimental diets) were used.

The following variables were measured: egg weight (EW), specific gravity (SG), albumen height (AH), Haugh unit (HU), egg yolk weight (YW), albumen weight (AW), shell weight (SW) and shell thickness (ST), pH of yolk and albumen, and yolk color (YC). Whole egg, yolk, albumen, and shell weight were measured on a digital scale with an accuracy of $0.01 \mathrm{~g}$.

Specific gravity was measured at the same day of laying; cracked or soft-shelled eggs were not analyzed. For the evaluation, the eggs were placed in buckets with saline solutions ranging from 1,046 to 1,090 , totaling 12 solutions, checked with a petroleum densimeter. The eggs were removed as they floated, thus recording the respective density value corresponding to the bucket solution.

After breaking each egg for analysis of internal quality, the shells were washed for complete removal of the albumen adhered to the inner membrane. Subsequently, they were placed in a forced ventilation oven at $60^{\circ} \mathrm{C}$ for 24 hours and, when dry, EW and ST evaluations were performed. Shell thickness was measured at the equator of the egg using a digital micrometer.
TABLE I

Experimental diets of quails fed growing levels of soybean acid oil (SAO) in replacement of soybean oil (SO).

\begin{tabular}{|c|c|c|c|c|c|}
\hline $\begin{array}{l}\text { Ingredients } \\
\text { (kg) }\end{array}$ & SAO0 & SAO2 & SAO4 & SAO6 & SAO8 \\
\hline $\begin{array}{l}\text { Soybean } \\
\text { meal, } 46 \%\end{array}$ & 40.80 & 40.80 & 40.80 & 40.80 & 40.80 \\
\hline Corn & 37.00 & 37.00 & 37.00 & 37.00 & 37.00 \\
\hline Soybean oil & 8.00 & 6.00 & 4.00 & 2.00 & 0.00 \\
\hline $\begin{array}{l}\text { Soybean } \\
\text { acid oil }\end{array}$ & 0.00 & 2.00 & 4.00 & 6.00 & 8.00 \\
\hline $\begin{array}{l}\text { Vitamin- } \\
\text { Mineral } \\
\text { Premix * }\end{array}$ & 5.00 & 5.00 & 5.00 & 5.00 & 5.00 \\
\hline Limestone & 4.50 & 4.50 & 4.50 & 4.50 & 4.50 \\
\hline $\begin{array}{l}\text { Dicalcium } \\
\text { phosphate }\end{array}$ & 2.50 & 2.50 & 2.50 & 2.50 & 2.50 \\
\hline Inert & 1.70 & 1.70 & 1.70 & 1.70 & 1.70 \\
\hline $\begin{array}{l}\text { DL- } \\
\text { methionine }\end{array}$ & 0.30 & 0.30 & 0.30 & 0.30 & 0.30 \\
\hline $\begin{array}{c}\text { L-lysine } \\
\text { HCL }\end{array}$ & 0.10 & 0.10 & 0.10 & 0.10 & 0.10 \\
\hline Salt & 0.10 & 0.10 & 0.10 & 0.10 & 0.10 \\
\hline Total & 100.00 & 100.00 & 100.00 & 100.00 & 100.00 \\
\hline
\end{tabular}

$\mathrm{SAO} 0=0 \%$ soybean acid oil $+8 \%$ soybean oil; $\mathrm{SAO} 2=2 \%$ soybean acid oil $+6 \%$ soybean oil; $\mathrm{SAO} 4=4 \%$ soybean acid oil $+4 \%$ soybean oil; SAO6 $=6 \%$ soybean acid oil $+2 \%$ soybean oil; $\mathrm{SAO} 8=8 \%$ soybean acid oil $+0 \%$ soybean oil. *Vitamin-Mineral Premix (warranty levels/kg of diet): folic acid ( $\mathrm{min}) 0.8 \mathrm{mg}$; pantothenic acid (min) $10 \mathrm{mg}$; zinc bacitracin $30 \mathrm{mg}$; biotin ( $\mathrm{min}$ ) $0.07 \mathrm{mg}$; calcium (min-max) 7.5-10g; cobalt (min) $0.15 \mathrm{mg}$; copper ( $\mathrm{min}) 12 \mathrm{mg}$; choline (min) $1.5 \mathrm{~g}$; iron ( $\mathrm{min}) 50 \mathrm{mg}$; phosphorus (min) $2.25 \mathrm{~g}$; iodine (min) $1.4 \mathrm{mg}$; manganese (min) $70 \mathrm{~g}$; DL-methionine (min) $0.5 \mathrm{~g}$; niacin ( $\mathrm{min}) 42 \mathrm{mg}$; sodium $(\mathrm{min}) 1.5 \mathrm{~g}$; selenium ( $\mathrm{min}$ ) $0.15 \mathrm{mg}$; vit. A (min) $10,000 \mathrm{IU}$; vit. $\mathrm{B}_{1}(\mathrm{~min}) 2 \mathrm{mg}$; vit. $\mathrm{B}_{2}$ (min) 6mg; vit. $B_{12}$ (min) $21.5 \mathrm{mcg}$; vit. $B_{6}$ (min) $2.75 \mathrm{mg}$; vit. $\mathrm{D}_{3}$ (min) 2,100IU; vit. E (min) 27IU; Vit. $\mathrm{K}_{3}$ (min) $2.5 \mathrm{mg}$; zinc (min), 90mg.

The HU was obtained from the logarithmic relationship between egg weight and albumen height, where $\mathrm{HU}=100 \log \left(\mathrm{H}+7.57-1.7 \mathrm{~W}^{0.37}\right)$, where $\mathrm{H}=$ height of thick albumen $(\mathrm{mm}), \mathrm{W}=$ weight of egg $(\mathrm{g})$.

Two methods were used to evaluate YC. In the first method, we used a colorimetric fan which contains scores of shades ranging from 1 to 15 for visual 
TABLE II

Soybean acid oil (SAO) profile.

\begin{tabular}{|c|c|}
\hline Oleic acid acidity $(\%, \mathrm{~m} / \mathrm{m})$ & 64.68 \\
\hline Ether extract $(\%)$ & 95.77 \\
\hline \multicolumn{2}{|c|}{ Fatty acids (\%) } \\
\hline Unsaturated fats & 71.22 \\
\hline Polyunsaturated fatty acids & 46.36 \\
\hline Monounsaturated fats & 24.86 \\
\hline Saturated fats & 24.55 \\
\hline \multicolumn{2}{|c|}{ Fatty acid profile (g/100g) } \\
\hline Linoleic acid (C18:2n6c) & 41.54 \\
\hline Oleic acid (C18:1n9c) & 23.83 \\
\hline Palmitic acid (C16:0) & 15.56 \\
\hline Stearic acid (C18:0) & 6.45 \\
\hline
\end{tabular}

comparison with egg yolk colors. The second method, through a tri-stimulus colorimeter (color, hue, and brightness) used a Minolta apparatus previously calibrated on a white surface.

We obtained values of chroma L, which gives us the luminosity with a variation of white $(L=100)$ to black $(\mathrm{L}=0)$, of chroma $\mathrm{a}^{*}$, which characterizes the coloration of red $\left(+\mathrm{a}^{*}\right)$ to green $\left(-\mathrm{a}^{*}\right)$, and of chroma $b^{*}$, which characterizes the coloration from yellow $\left(+b^{*}\right)$ to blue $\left(-b^{*}\right)$.

To verify egg quality over storage time, 400 eggs from the birds that were fed for eight weeks with the experimental diets were stored for up to 28 days at $23^{\circ} \mathrm{C} \pm 1$.

Internal egg quality analysis was performed at $0,7,14,21$, and 28 days of storage. The variables studied were the same as those related to egg quality in fresh eggs.

\section{SENSORY ANALYSIS OF EGGS}

Sensory analysis was carried out in the last production cycle, in which the eggs were collected over a period of five days and identified according to the corresponding treatment. The eggs were stored under refrigeration prior to evaluation at the Laboratory of Meat and Sensory Analysis of the Department of Animal Science, UFPel, Brazil.
Sensory evaluations were conducted in individual compartments, with no noise and no odor, at pre-established hours, excluding one hour before and two hours after lunch, according to the method described in Moraes (1985).

The panel of assessors consisted of ten trained people of both sexes and different ages. The selection of candidates to compose the panel was followed through the adaptation of the methodology described by Seibel et al. (2010). After the training period, the assessors performed evaluations during three sessions. In each session, the eggs were boiled for seven minutes, allowed to cool to room temperature, and then peeled with the aid of a quail egg peeler machine, thus maintaining a pattern of appearance and integrity thereof.

Samples encoded with random three-digit numbers were served with salt biscuits and mineral water at room temperature (to remove aftertaste), with coffee beans (to remove odor) between the samples.

In all sessions, the assessors in their individual compartments were instructed to evaluate one sample at a time from left to right. To avoid visual discrimination of the samples by color, the compartments had a red light on, with the exception for the color attributes evaluation.

In the first session, the evaluation was performed through the sensorial attributes of the eggs on a structured $11 \mathrm{~cm}$ scale, anchored in the leftmost ends by the term "little or absent" and to the right by the term "strong or very strong ", in which two treatments were evaluated (SAO vs. SO). The assessors received a score sheet to evaluate odor (characteristic to egg) and taste (acid, residual, rancid, and characteristic of oil) and, lastly, the attributes of color (yellow intensity and brightness) with the red light off.

In the second evaluation session, the duo-trio discriminatory test was performed. This procedure allows detecting sensorial differences between a sample and a standard. The standard and two coded 
TABLE III

Soybean oil profile.

\begin{tabular}{cccccc}
\hline \multirow{2}{*}{$\begin{array}{c}\text { Fatty acid } \\
(\mathbf{g} / \mathbf{1 0 0 g})\end{array}$} & SAO & \begin{tabular}{c} 
Machado et al. \\
\cline { 3 - 6 }
\end{tabular} & $\mathbf{2 0 0 8}$ & $\begin{array}{c}\text { Cunha } \\
\mathbf{2 0 0 8}\end{array}$ & \multicolumn{2}{c}{$\begin{array}{c}\text { Aued-Pimentel } \\
\mathbf{2 0 0 9}\end{array}$} & ANVISA* \\
\hline Linoleic acid & 41.54 & 54.2 & 46.48 & $48.11-54.65$ & $44.0-62.0$ \\
Oleic acid & 23.83 & 23.1 & 34.77 & $22.57-25.82$ & $19.0-30.0$ \\
Palmitic & 15.56 & 11.3 & 12.52 & $10.27-12.17$ & $7.0-14.0$ \\
Stearic acid & 6.45 & 3.5 & 4.89 & $2.67-4.77$ & $1.4-5.5$ \\
\hline
\end{tabular}

*Agência Nacional de Vigilância Sanitária, Brazil.

samples were simultaneously presented to the assessors who should identify the sample equal to the standard (IAL 2008).

For the third evaluation session, the triangular test was used. This procedure is similar to the previous test; however, in this case, three coded samples are presented simultaneously, two being equal and one being different. The assessors must identify the different sample with a probability of correct $P=1 / 3$. As in the previous session test, the interpretation of the result is based on the total number of trials versus the number of correct judgments.

\section{STATISTICAL ANALYSIS}

A completely randomized experimental arrangement was used. Each one of the cages (two birds per cage) was considered an experimental unit. Analysis of variance with repeated measurements and Tukey's test to separate means were used. Appropriate covariance structures

were chosen based on the Akaike information criterion. The statistical model was Yijk $=\mu+$ $\mathrm{di}+\mathrm{hij}+\mathrm{wk}+\mathrm{dwik}+$ eijk, where: $\mu=$ average mean; $\mathrm{di}=$ diet fixed effect ( $\mathrm{i}=1$ to 5 diets); hij = random effect of cage within the dietary treatment (treatment; $\mathrm{j}=1$ to 8 , number of cages/treatment); $\mathrm{wk}=$ fixed effect during laying period ( $\mathrm{k}=1$ to 2 ); $\mathrm{dwjk}=$ interaction between diet and laying period (treatment $\mathrm{x}$ period); eijk = random error (residual error).
A polynomial regression analysis was performed to estimate the effect of replacement levels of SO by SAO. The effect of the oil type on the sensorial attributes of the eggs in a structured scale were evaluated by Student's t test for paired data. All analysis were performed in the R software (R Core Team 2015), with significant differences at the probability level of $5 \%$.

\section{RESULTS AND DISCUSSION}

Egg quality parameters can be influenced by productive performance of the birds. In this sense, we found that supplementation with SAO over a period of 56 days had no effect on feed intake, rate of egg production, and body weight (data not shown).

\section{EFFECTS OF ACID OILS ON EGG QUALITY}

The egg quality results of quails fed with increasing levels of SAO are shown in Table IV. Based on the results, EW, HU, SG, AW, YW, SW, and ST were not affected $(\mathrm{P}>0.05)$ by the inclusion of increasing levels of SAO in the quail diet.

Alterations in the internal and external quality of the eggs are expected with FFA-rich diets, since these could interfere with the absorption and dietary nutrient availability, reducing the ingredient's metabolizability. However, the quality obtained with the SAO was comparable to the egg quality results of the control treatment. 
The eggs in all treatments presented excellent internal quality, with mean Haugh unit values above 94 (Table IV). The loss of carbon dioxide through the pores of quail eggshells is lower than that of chicken hens because of the greater thickness of the quail eggshell membranes, which may allow maintenance of albumen height.

Egg yolk percentage and weight did not differ $(\mathrm{P}>0.05)$ between SAO inclusion levels in the quail diet (Table IV). As stated by Balvane (1970), diets deficient in linoleic acid affect the weight of the components of hen eggs, reducing their weight by up to $10 \mathrm{~g}$, with the yolk being the most affected part. The SAO used in the present study contained $41.5 \%$ of linoleic fatty acid-omega 6 . The levels of linoleic acid in refined soybean oil may vary from 48.1 to $54.6 \%$ (Aued-Pimentel et al. 2009); therefore, a reduction in egg size could be expected only if the diets were deficient in linoleic acid.

However, the literature presents conflicting data regarding the use of linoleic acid to increase egg weight.

Ribeiro et al. (2007) observed that birds fed the highest level of linoleic acid (1.93\% vs. $1.48 \%$ ) produced heavier eggs than broiler breeds fed lower levels of linoleic acid in the diet. On the other hand, Grobas et al. (2001) clearly indicated that increased egg weight is more associated with total fat content in the diet than with linoleic acid content.

The specific gravity values were not influenced by the increasing levels of SAO in quail diets (Table IV), with an average of 1,075 in the treatments studied; these values were higher than those found by Nowaczewski et al. (2010), who obtained SG value of $1,059,1,052$, and 1,046 for 9,25 , and 31 weeks of age, respectively. This result indicates that the quality of the eggs in the present experiment was not impaired; despite the inclusion of oil was $1 \%$ higher than the maximum recommended by Rostagno et al. (2011), based on better productive performance, which is $7 \%$ in laying hen diets.
There were no differences between the diets with SO and those with increasing levels of SAO in terms of AW, YW, and SW as well as the percentages of albumen, yolk, and shell (Table IV).

Although there was a significant effect of diet on both albumen height and Haugh unit, there was no consistent relationship between those parameters and the level of SAO.

As shown in Table IV, birds fed with increasing levels of SAO produced eggs with more pigmented yolks compared to those fed a control diet (SO), based on the colorimetric fan (visual score) and the tri-stimulus colorimeter values (color, hue, and brightness). These results indicate that the carotenoids present in the SAO were transferred linearly to the egg yolk, resulting in more orange colored yolk with the highest level of SAO.

There was a linear $(\mathrm{P}<0.001)$ effect of increasing levels of SAO for red chroma $\left(\mathrm{a}^{*}=-5.26\right.$ $\left.+0.14 \mathrm{x}, \mathrm{R}^{2}=0.89, \mathrm{P}=0.01\right)$ and yellow chroma $\left(b^{*}=42.32+0.44 \mathrm{x}, \mathrm{R}^{2}=0.88 \mathrm{P}=0.01\right)$. There were no differences for $\mathrm{L}^{*}$ (luminosity).

The results of the regression analysis showed a linear increase in yellow color intensity ( $\mathrm{Y}=4.92$ $\left.+0.15 \mathrm{x}, \mathrm{R}^{2}=0.94, \mathrm{P}<0.0001\right)$ in the yolks with higher levels of SAO in the diet when evaluated by a colorimetric fan.

For quail eggs, which are mostly consumed whole (cooked or preserved), partly due to their small size, the color of the yolk is not a feature of great concern. However, the results of this study could be transferred to laying hens; in chicken eggs, this variable is of much greater relevance. According to Osawa et al. (2006), the pigment content of crude oils is high and may have a carotenoid value between 40 and $50 \mathrm{mg} / \mathrm{kg}$.

\section{EFFECT OF INTERACTION OF ACID OILS WITH SHELF LIFE OF EGGS}

Table $\mathrm{V}$ shows the results obtained from storing the eggs over a period of $0,7,14,21$, and 28 days. Similar to the results obtained for fresh eggs, with 
TABLE IV

Quality of fresh eggs of quails fed with increasing levels of soybean acid oil as replacer of soybean oil in the diet.

\begin{tabular}{|c|c|c|c|c|c|c|c|c|c|c|c|}
\hline \multirow[b]{2}{*}{ Variable } & \multicolumn{5}{|c|}{ Diets } & \multirow[b]{2}{*}{$S E M$} & \multicolumn{5}{|c|}{ P-value } \\
\hline & $\begin{array}{c}\text { SAO } \\
0\end{array}$ & $\begin{array}{c}\text { SAO } \\
2\end{array}$ & $\begin{array}{c}\text { SAO } \\
4\end{array}$ & $\begin{array}{c}\text { SAO } \\
6\end{array}$ & $\begin{array}{c}\text { SAO } \\
8\end{array}$ & & D & $\mathbf{P}$ & DP & $\mathbf{L}$ & $\mathbf{Q}$ \\
\hline EW (g) & 13.74 & 14.06 & 13.87 & 13.57 & 13.69 & 0.12 & ns & $* *$ & ns & ns & ns \\
\hline $\mathrm{SG}\left(\mathrm{g} / \mathrm{m}^{3}\right)$ & 1.076 & 1.075 & 1.077 & 1.074 & 1.075 & 0.53 & ns & $* * *$ & $\mathrm{~ns}$ & $\mathrm{~ns}$ & $\mathrm{~ns}$ \\
\hline $\mathrm{AH}(\mathrm{mm})$ & 6.13 & 6.29 & 6.07 & 5.71 & 6.32 & 0.06 & $* *$ & $* *$ & ns & ns & ns \\
\hline $\mathrm{HU}$ & 96.43 & 96.98 & 96.10 & 94.51 & 97.37 & 0.27 & $* *$ & $* *$ & ns & ns & ns \\
\hline AW (g) & 7.23 & 7.38 & 7.31 & 7.03 & 7.04 & 0.09 & ns & $* * *$ & ns & ns & ns \\
\hline YW (g) & 4.65 & 4.86 & 4.77 & 4.70 & 4.71 & 0.04 & ns & ns & ns & ns & ns \\
\hline SW (g) & 1.24 & 1.28 & 1.25 & 1.23 & 1.23 & 0.01 & ns & ns & ns & ns & ns \\
\hline ST (mm) & 0.287 & 0.295 & 0.296 & 0.292 & 0.299 & 0.002 & ns & ns & $\mathrm{ns}$ & ns & ns \\
\hline \multicolumn{12}{|c|}{ Yolk color } \\
\hline $\mathrm{L}^{*}$ & 60.74 & 60.15 & 61.15 & 60.02 & 59.22 & 0.24 & ns & ns & ns & ns & ns \\
\hline$a^{*}$ & -5.29 & -4.77 & -4.89 & -4.43 & -4.03 & 0.08 & $* * *$ & ns & $* *$ & $* * *$ & ns \\
\hline$b^{*}$ & 42.01 & 43.83 & 43.56 & 45.35 & 45.63 & 0.37 & ns & ns & $\mathrm{ns}$ & $* * *$ & ns \\
\hline Fan score & 4.82 & 5.43 & 5.43 & 5.80 & 6.17 & 0.08 & $* * *$ & $*$ & $* *$ & $* * *$ & $\mathrm{~ns}$ \\
\hline
\end{tabular}

$\mathrm{SAO} 0=0 \%$ soybean acid oil $+8 \%$ soybean oil; $\mathrm{SAO} 2=2 \%$ soybean acid oil $+6 \%$ soybean oil; $\mathrm{SAO} 4=4 \%$ soybean acid oil $+4 \%$ soybean oil; $\mathrm{SAO} 6=6 \%$ soybean acid oil $+2 \%$ soybean oil; SAO8 $=8 \%$ soybean acid oil $+0 \%$ soybean oil.

EW = Egg weight. $\mathrm{SG}=$ Specific gravity. $\mathrm{AH}=$ Albumen height. $\mathrm{HU}=$ Haugh Unit. AW = Albumen weight. YW = yolk weight. $\mathrm{SW}=$ Shell weight. ST $=$ Shell thickness. $\mathrm{SEM}=$ Standard error of mean. $\mathrm{D}=$ diet. $\mathrm{P}=$ period. $\mathrm{DP}=$ diet $v$ s. period. $\mathrm{L}=$ linear. $\mathrm{Q}$ $=$ quadratic. ${ }^{\mathrm{n}}$ Non significant $(\mathrm{P}>0.05) .{ }^{*} \mathrm{P}<0.05 .{ }^{*} * \mathrm{P}<0.01 .{ }^{*} * \mathrm{P}<0.001$.

the exception of yolk color, no differences between treatments were found for any of the analyzed variables.

Higher levels of carotenoids present in SAO diets contributed directly to increasing intensities of the red color $\left(\mathrm{a}^{*}=-5.30+0.15 \mathrm{x}, \mathrm{R}^{2}=0.93, \mathrm{P}=\right.$ 0.007), during storage time according to the level of SAO inclusion in the diet (Table V). Similar results were obtained with the use of the colorimetric fan $\left(\mathrm{Y}=4.42+0.13, \mathrm{R}^{2}=0.92, \mathrm{P}<0.0001\right)$. It is already well documented that egg quality losses occur with increasing storage time at room temperature. After laying, egg quality loss inevitably starts and may be more pronounced depending on factors such as microbiological contamination, humidity elevation, and temperatures above $8^{\circ} \mathrm{C}$ (Barbosa et al. 2008).

Internal egg quality is highly dependent on storage conditions. Eggs stored at high ambient temperatures may undergo chemical reactions that accelerate the degradation process (Moura et al.
2008). According to Santos et al. (2009), dense albumen height and yolk index are internal quality factors that are related to egg weight decrease due to evaporation of water to the external medium during storage. The loss of water and $\mathrm{CO}_{2}$, although occurring naturally and continuing over the storage period, can be delayed under refrigeration (Oliveira 2006).

In the same way, significant egg quality losses $(\mathrm{P}<0.001)$ were observed during storage in terms of specific gravity, albumen height, weight loss of the yolk and albumen, yolk color, as well as the $\mathrm{pH}$ of yolk and albumen (Table V).

The $\mathrm{pH}$ of the eggs was maintained within neutrality, presenting a centralized yolk and dense and high albumen, with no differences between increasing levels of SAO in the diets. However, differences $(\mathrm{P}<0.0001)$ were found in relation to the storage period (Table V). The HU values 
TABLE V

Effect of storage time on quality of quail eggs after eight weeks. Quails were fed with increasing levels of soybean acid oil as replacer of soybean oil in the diet.

\begin{tabular}{|c|c|c|c|c|c|c|c|c|c|c|c|}
\hline \multirow[b]{2}{*}{ Variable } & \multicolumn{5}{|c|}{ Diets } & \multirow[b]{2}{*}{$S E M$} & \multicolumn{5}{|c|}{ P-value } \\
\hline & $\begin{array}{c}\text { SAO } \\
\mathbf{0}\end{array}$ & $\begin{array}{c}\text { SAO } \\
2\end{array}$ & $\begin{array}{c}\text { SAO } \\
4\end{array}$ & $\begin{array}{c}\text { SAO } \\
6\end{array}$ & $\begin{array}{c}\text { SAO } \\
8\end{array}$ & & D & $\mathbf{P}$ & DP & $\mathbf{L}$ & $\mathbf{Q}$ \\
\hline EW (g) & 15.28 & 15.29 & 15.69 & 15.33 & 15.81 & 0.10 & ns & ns & ns & ns & ns \\
\hline $\mathrm{SG}\left(\mathrm{g} / \mathrm{m}^{3}\right)$ & 1.069 & 1.071 & 1.070 & 1.066 & 1.069 & 0.07 & ns & $* * *$ & ns & ns & $\mathrm{ns}$ \\
\hline $\mathrm{AH}(\mathrm{mm})$ & 4.85 & 4.84 & 4.67 & 4.54 & 5.12 & 0.10 & ns & $* * *$ & ns & ns & ns \\
\hline $\mathrm{HU}$ & 88.6 & 88.3 & 87.2 & 86.5 & 89.7 & 0.58 & ns & $* * *$ & ns & ns & ns \\
\hline WL (g) & 0.13 & 0.13 & 0.12 & 0.14 & 0.11 & 0.01 & ns & $* * *$ & ns & ns & ns \\
\hline WL (\%) & 0.87 & 0.86 & 0.72 & 0.97 & 0.71 & 0.07 & ns & $* * *$ & ns & ns & ns \\
\hline AW (g) & 6.94 & 6.95 & 7.25 & 6.77 & 7.35 & 0.09 & ns & $* * *$ & ns & ns & ns \\
\hline AW (\%) & 45.2 & 45.3 & 45.6 & 44.0 & 46.4 & 0.44 & ns & $* * *$ & ns & ns & ns \\
\hline YW (g) & 4.96 & 4.96 & 5.12 & 5.05 & 5.15 & 0.04 & ns & $* * *$ & ns & ns & ns \\
\hline YW (\%) & 32.6 & 32.5 & 32.9 & 33.1 & 32.6 & 0.26 & ns & $*$ & ns & ns & ns \\
\hline SW (g) & 1.30 & 1.31 & 1.29 & 1.25 & 1.27 & 0.01 & ns & ns & ns & ns & ns \\
\hline $\mathrm{ST}(\mathrm{mm})$ & 0.299 & 0.304 & 0.300 & 0.299 & 0.299 & 0.002 & ns & ns & ns & ns & ns \\
\hline \multicolumn{12}{|c|}{ Yolk color } \\
\hline $\mathrm{L}^{*}$ & 65.7 & 64.97 & 65.4 & 64.97 & 64.81 & 0.30 & ns & $* * *$ & ns & ns & ns \\
\hline$a^{*}$ & -5.44 & -4.85 & -4.67 & -4.29 & -4.21 & 0.08 & $* *$ & $* *$ & ns & $* * *$ & $\mathrm{~ns}$ \\
\hline$b^{*}$ & 48.6 & 51.32 & 50.84 & 52.62 & 51.92 & 0.48 & $*$ & $* * *$ & ns & ns & $\mathrm{ns}$ \\
\hline Fan score & 4.31 & 4.76 & 4.97 & 5.33 & 5.32 & 0.08 & $* *$ & $* * *$ & ns & $* * *$ & $\mathrm{~ns}$ \\
\hline $\mathrm{pH}$ yolk & 6.23 & 6.12 & 6.17 & 6.23 & 6.22 & 0.04 & ns & $* * *$ & ns & ns & ns \\
\hline $\mathrm{pH}$ albumen & 9.51 & 9.56 & 9.53 & 9.53 & 9.52 & 0.01 & ns & $* * *$ & ns & ns & ns \\
\hline
\end{tabular}

$\mathrm{SAO} 0=0 \%$ soybean acid oil $+8 \%$ soybean oil; $\mathrm{SAO} 2=2 \%$ soybean acid oil $+6 \%$ soybean oil; SAO4 $=4 \%$ soybean acid oil $+4 \%$ soybean oil; SAO6 $=6 \%$ soybean acid oil $+2 \%$ soybean oil; SAO8 $=8 \%$ soybean acid oil $+0 \%$ soybean oil.

$\mathrm{EW}=$ Egg weight. $\mathrm{SG}=$ Specific gravity. $\mathrm{AH}=$ Albumen height. $\mathrm{HU}=$ Haugh Unit. $\mathrm{WL}=$ Weight loss. AW $=$ Albumen weight. YW $=$ Yolk weight. $\mathrm{SW}=$ Shell weight. $\mathrm{ST}=$ Shell thickness. $\mathrm{SEM}=$ Standard error of mean $. \mathrm{D}=$ diet. $\mathrm{P}=$ length of storage. $\mathrm{DP}=$ diet vs. length of storage. $\mathrm{L}=$ linear. $\mathrm{Q}=$ quadratic. ${ }^{\mathrm{n}}$ Non significant $(\mathrm{P}>0.05) . * \mathrm{P}<0.05$. $* * \mathrm{P}<0.01 . * * * \mathrm{P}<0.001$

remained between 86 and 89 up to 14 days of storage at room temperature $\left(23 \pm 1{ }^{\circ} \mathrm{C}\right)$.

The loss of yolk color intensities during storage can be explained by the oxidation of the double bonds present in the molecules of carotenoids (Barbosa et al. 2011).

Carotenoids and xanthophylls, as well as pigments, are also characterized as important antioxidants. Therefore, in the present study, the higher levels of acidity of the diets with the increase of SAO inclusion levels did not influence the quality characteristics of eggs, probably due to the higher concentration of these pigments present in SAO compared to SO.

This hypothesis is in agreement with Freitas et al. (2011), who concluded that antioxidants and feed additives may have favored the preservation of the percentage of yolk in relation to the whole egg.

\section{EFFECTS OF ACID OILS ON SENSORY EVALUATION}

Table VI shows the mean values of the sensory attributes for the two treatments tested (SAO vs. 
TABLE VI

Averages \pm standard deviation of sensory attributes evaluated by trained assessors in egg samples of quails fed diets with soybean acid oil (SAO) or refined soybean oil (SO).

\begin{tabular}{cccc}
\hline Attributes $^{\mathbf{1}}$ & SAO & SO & P-value \\
\hline Color & $4.70 \pm 1.97$ & $2.65 \pm 2.01$ & 0.02 \\
Brightness & $4.89 \pm 2.25$ & $4.93 \pm 2.90$ & 0.51 \\
Odor & $5.61 \pm 1.90$ & $4.30 \pm 1.51$ & 0.02 \\
Toughness & $6.54 \pm 2.41$ & $5.60 \pm 1.97$ & 0.15 \\
Acid taste & $3.40 \pm 3.68$ & $2.63 \pm 2.76$ & 0.07 \\
Aftertaste & $4.71 \pm 2.05$ & $3.26 \pm 2.26$ & 0.02 \\
Rancid taste & $2.61 \pm 3.20$ & $1.14 \pm 2.29$ & 0.06 \\
$\begin{array}{c}\text { Oil characteristic } \\
\text { taste }\end{array}$ & $5.48 \pm 2.55$ & $4.17 \pm 2.25$ & 0.08 \\
\hline
\end{tabular}

${ }^{1}$ Structured $11 \mathrm{~cm}$ scale $(1=$ lowest intensity, $11=$ highest intensity).

$\mathrm{SO})$ in a structured scale of $11 \mathrm{~cm}(1=$ lowest intensity, 11 = highest intensity).

The results demonstrated, at a $5 \%$ probability level, that SO replacement by SAO in quail diets increased color intensity, egg odor, and aftertaste.

The increase in color intensity in quail eggs fed $8 \%$ SAO was observed with a colorimeter and with subjective evaluations, showing that there was a consistency between the analyses carried out.

Therefore, the most likely explanation for the increase in color $(\mathrm{P}=0.02)$ is due to the higher value of pigments present in the acid oil as compared to refined soybean oil (Pinheiro et al. 2013), which are directly transferred into the egg yolk.

We observed a linear increase in K270 by increasing the dietary SAO (data not shown), indicating the formation of secondary oxidative compounds. The oxidation of the oils occurs in two stages: the first stage is characterized by hydroperoxide formation, while in the second stage, proliferation of hydroperoxides occurs, which are transformed into secondary oxidation compounds (Gharby et al. 2015) such as aldehydes and ketones, causing unpleasant taste and odor of oils and fats.
In this sense, the increase in the intensity of the aftertaste $(P=0.02)$ and even rancidity $(P=0.06)$ observed by the assessors (Table VI) may be due to the greater amounts of products of decomposition of the hydroperoxides in acid oil, which may have been transferred to the egg.

Differences between treatments were also demonstrated by the "duo-trio" discriminating test, in which the assessors were able to recognize which of the two samples was different from the standard, since the number of hits was eight in 10 trials $(\mathrm{P}=$ 0.04 , binomial distribution, $\mathrm{n}=10$, probability $=$ $0.5)$.

These results were not confirmed in the triangular test, in which the probability of random success decreased to $1 / 3$. In this case, the assessors had difficulties recognizing the different sample presenting a number of hits of only three out of 10 possibilities $(\mathrm{P}=0.26$, binomial distribution, $\mathrm{n}=10$, probability $=0.33$ ). Although there were significant differences between SAO and SO in the "duo-trio" discriminating test, the attributes reached normal values, with no evidence of rejection of the product by the assessors.

\section{CONCLUSIONS}

Internal and external quality variables of fresh and stored quail eggs are not affected by the addition of soybean acid oil to the diet, with the exception of yolk color intensity, which increased linearly with the inclusion of SAO.

The inclusion of SAO in quail diets does not change the internal quality of eggs stored at room temperature of $\left(23^{\circ} \mathrm{C}\right)$ for 28 days.

Internal egg quality decreases linearly over a storage time of up to 28 days.

Trained assessors can detect differences in yolk color intensity, odor, and aftertaste of eggs from quails fed SAO. 


\section{REFERENCES}

AUED-PIMENTEL S, KUMAGAI EE, KUS MMM, CARUSO MSF, TAVARES M AND ZENEBON O. 2009. Ácidos graxos trans em óleos vegetais refinados poliinsaturados comercializados no estado de São Paulo, Brasil. Ciênc Tecnol Aliment 29: 646-651.

BALVANE D. 1970. Essential fatty acids in poultry nutrition. Worlds Poult Sci J 26: 442-460.

BARBOSA VC, GASPAR A, CALIXTO LFL AND AGOSTINHO TSP. 2011. Stability of the pigmentation of egg yolks enriched with omega-3 and carophyll stored at room temperature and under refrigeration. R Bras Zootec 40: $1540-1544$.

BARBOSA VM, CANCADO SV, BAIAO NC, LANA AMQ, LARA LJC AND SOUZA MR. 2008. Effects of relative air humidity in the hatchery and breeder hen age on the incubation yield. Arq Bras Med Vet Zootec 60: 741-748.

CUNHA ME. 2008. Caracterização de biodiesel produzido com misturas binárias de sebo bovino, óleo de frango e óleo de soja 86 f. Dissertação (Mestrado em Química) Instituto de Química, Universidade Federal do Rio Grande do Sul, 2008. (Unpublished).

FREITAS ER, SAKOMURA NK, NEME R AND SANTOS AD. 2005. Valor energético do óleo ácido de soja para aves. Pesq Agropec Bras 40: 241-246.

FREITAS LW, PAZ ICLA, GARCIA RG, CALDARA FR, SENO LO, FELIX GA, LIMA NDS, FERREIRA VMOS AND CAVICHIOLO F. 2011. Aspectos qualitativos de ovos comerciais submetidos a diferentes condições de armazenamento. Rev Agrarian 4: 66-72.

GHARBY S, HARHAR H, BOUZOUBAÂ Z, ELMADANI N AND CHARROUF Z. 2015. The Effect of Storage Conditions and Roasting Kernels on Extra Virgin Argan Oil Quality. J Mat Environ Sci 6: 254-263.

GROBAS S, MENDEZ J, LAZARO R, DE BLAS C AND MATEO GG. 2001. Influence of source and percentage of fat added to diet on performance and fatty acid composition of egg yolk of two strains of laying hens. Poult Sci 80 : 1171-1179.

IAL - INSTITUTO ADOLFO LUTZ. 2008. Normas analíticas do Instituto Adolfo Lutz: Métodos físico-químicos para análise de alimentos, $4^{\mathrm{a}}$ ed., $1^{\mathrm{a}}$ Edição Digital, São Paulo, $1020 \mathrm{p}$.

JIANG Q. 2014. Natural forms of vitamin E: metabolism, antioxidant and anti-inflammatory activities and the role in disease prevention and therapy. Free Radic Biol Med 72: 76-90.

MACHADO ER, DOBARGANES GARCIA MC AND ABRANTES SMP. 2008. Alterações dos óleos de palma e de soja em fritura descontínua de batatas. Ciênc Tecnol Aliment 28: 786-792.
MORAES MAC. 1985. Métodos para avaliação sensorial dos alimentos, $5^{\text {a }}$ ed., Campinas: Unicamp, 85 p.

MOUNTS TL. 1981. Chemical and physical effects of processing fats and oils. J Am Oil Chem Soc 58: 51-54.

MOURA AMAD, FONSECA JB, MELO EDA, LIMA VLAGD, SANTOS PAD AND SILVA QJD. 2009. Características sensoriais de ovos de codornas japonesas (Coturnix japônica, Temminck e Schlegel, 1849) suplementadas com pigmentantes sintéticos e selenometionina. Ciênc Agrotec 33: 1594-1600.

MOURA AMAD, OLIVEIRA NTED, THIEBAUT JTL AND MELO TV. 2008. Efeito da temperatura de estocagem e do tipo de embalagem sobre a qualidade interna de ovos de codornas japonesas (Coturnix japonica). Ciênc Agrotec 32: $578-582$.

NOWACZEWSKI S, KONTECKA H, ROSIŃSKI A, KOBERLING S AND KORONOWSKI P. 2010. Egg quality of Japanese quail depends on layer age and storage time. Folia Biol 58: 201-207.

OLIVEIRA GE. 2006. Influência da temperatura de armazenamento nas características físico-químicas e nos teores de aminas bioativas em ovos. 79 f. Dissertação (Mestrado em Ciência de Alimentos) - Faculdade de Farmácia, Universidade Federal de Minas Gerais, Belo Horizonte. (Unpublished).

ORMENESE RDCS, MISUMI L, ZAMBRANO F AND FARIA EVD. 2004. Influência do uso de ovo líquido pasteurizado e ovo desidratado nas características da massa alimentícia. Ciênc Tecnol Aliment 24: 255-260.

OSAWA CC, GONÇALVES LAG AND RAGAZZI S. 2006. Titulação potenciométrica aplicada na determinação de ácidos graxos livres de óleos e gorduras comestíveis. Quim Nova 29: 593-599.

PARDIO VT, LANDIN LA, WALISZEWSKI KN, BADILLO C AND PEREZ-GIL F. 2001. The effect of acidified soapstocks on feed conversion and broiler skin pigmentation. Poult Sci 80: 1236-1239.

PARDIO VT, LANDIN LA, WALISZEWSKI KN, PÉREZGIL F, DIAZ L AND HERNANDEZ B. 2005. The effect of soybean soapstock on the quality parameters and fatty acid composition of the hen egg yolk. Poult Sci 84: 148157.

PINHEIRO JW, FONSECA NAN, SILVA CA, OBA A, BALARIN MRS AND BRUNELLI SR. 2013. Torta de girassol na alimentação de poedeiras semipesadas. Semin: Cienc Agrar 34: 3959-3970.

R CORE TEAM. 2015. R: A Language and Environment for Statistical Computing. R Foundation for Statistical Computing. Vienna, Austria.

RABER MR, RIBEIRO AML, KESSLER AM AND ARNAIZ V. 2009. Suplementação de glicerol ou de lecitina em diferentes níveis de ácidos graxos livres em dietas para frangos de corte. Ciênc Anim Bras 10: 745-753. 
RIBEIRO BRC, LARA LJC, BAIÃO NC, LOPEZ CAA, FIUZA MA, CANÇADO SV AND SILVA GMM. 2007. Efeito do nível de ácido linoléico na ração de matrizes pesadas sobre o peso, composição e eclosão dos ovos. Arq Bras Med Vet Zootec 59: 789-796.

ROSTAGNO HS, ALBINO LFT, DONZELE JL, GOMES PC, OLIVEIRA RT, LOPES DC AND EUCLIDES RF. 2011. Brazilian tables for poultry and swine. Composition of Feedstuffs and Nutritional Requirements, $3^{\text {rd }}$ ed., Brazil: UFV Viçosa.

SANTOS MDSVD, ESPÍNDOLA GB, LÔBO RNB, FREITAS ER, GUERRA JLL AND SANTOS ABE. 2009. Effect of temperature and storage of eggs. Food Sci Technol 29: 513-517.

SANTOS MV, ESPÍNDOLA G, LOBO RN, FUENTES MDF, CARVALHO L AND SANTOS AB. 2009. Desempenho e qualidade dos ovos de poedeiras comerciais submetidas às dietas com diferentes óleos vegetais. Rev Bras Saúde Prod An 10: 654-667.

SEIBEL NF, SCHOFFEN DB, QUEIROZ MI AND SOUZASOARES LD. 2010. Caracterização sensorial de ovos de codornas alimentadas com dietas modificadas. Ciênc Tecnol Aliment 30: 884-889.

SENKÖYLÜ N, AKYÜREK H, SAMLI HE AND YURDAKURBAN N. 2004. Performance and egg weight of laying hens fed on the diets with various by-product oils from the oilseed extraction refinery. Pak J Nutri 3: 38-42.

SILVA JHV, JORDÃO FILHO J, COSTA FGP, LACERDA PB, VARGAS DGV AND LIMA MR. 2012. Exigências nutricionais de codornas. Rev Bras Saúde Prod Anim 13: 775-790. 